\title{
O fora blanchotiano e o escritor engagé
}

João Luiz Peçanha Couto

UFF

\section{Resumo}

O presente artigo pretende, tomando como centro de discussóes dois ensaios de Maurice Blanchot, "A literatura e o direito à morte" ( $A$ parte do fogo), e "O encontro do imaginário" (O livro por vir), compreender a noção de escritor engajado como súmula ou resultante do fora blanchotiano, bem como discutir a afirmação da morte e do embate como sentidos da literatura, no contrafluxo da chamada palavra cotidiana. Para tanto, o enfrentamento crítico-teórico com a concepção sartreana de engajamento e de instituição da literatura como instrumento de transformação do mundo permitirá afirmar pistas para conferir ao "fora" estatuto de (re)apresentação no espaço literário.

Palavras-chave: fora; morte; narrativa; palavra literária.

\section{Resumen}

Este artículo tiene como objetivo -tomando como centro de la discusión dos ensayos de Maurice Blanchot, "La literatura y el derecho a la muerte" ( $\mathrm{La}$ parte del fuego), y "El encuentro con lo imaginário" (El libro por venir) - entender la noción de escritor comprometido como suma o resultante del fuera blanchotiano, así como discutir la afirmación de la muerte y de la lucha como sentidos de la literatura, en contravía de la palabra cotidiana. Para tanto, el enfrentamiento crítico-teórico con la concepción sartreana de compromiso, y de la institución literaria como instrumento de transformación del mundo, permitirá proponer pistas para dar al "fuera" el estatuto de (re)presentación en el espacio literario.

Palabras clave: fuera; muerte; narrativa; palabra literaria. 
1. HILL, Leslie. Blanchot: extreme contemporary, 1997, p. 107.

2. VASCONCELOS, Mauricio Salles de. "Blanchot, paradoxo plural”, 2002, p. 146.
$A$ arte é real na obra. A obra é real no mundo, porque ai se realiza [...] porque ela ajuda a sua realização e só terá sentido, só terá repouso, no mundo onde o homem será por excelência.

Maurice Blanchot

[a arte] gira segundo suas pequenas leis próprias mas, em última instância, de acordo com suas pequenas leis que fazem da obra sua única medida, trabalhará, o mais consciente e o mais rigorosamente possivel, na obra humana em geral e na afirmaçâo de um dia universal.

Maurice Blanchot

Todas as coisas do mundo não cabem numa ideia. Mas tudo cabe numa palavra, nesta palavra tudo.

Arnaldo Antunes

A literatura náo busca produzir sentido no mundo; em vez disso, tenta delir a palavra comum, substituindo-a por sua ausência absoluta - ausência esta irmanada com a escrita literária ${ }^{1}$, afirma Leslie Hill, professor da Universidade de Warwick, que estudou o trabalho do filósofo francês Maurice Blanchot em seu livro Blanchot: extreme contemporary, de 1997.

Nesse sentido, Blanchot investe a literatura de um viés desestabilizador e de negação do mundo, ao contrário de Sartre, que via nela uma função moral e positiva, uma quase tentativa de reconstrução utópica da vida por meio da arte/literatura. Esse olhar contrastivo, tendo de um lado Sartre (engajamento) e de outro Blanchot (certa inoperância atribuída à literatura) gerou uma peleja intelectual no mínimo interessante: em resposta a ideias expressas sobretudo no livro de Sartre (Que é literatura?, de 1947), Blanchot escreve o ensaio "A literatura e o direito à morte", que ora comentamos.

Nesse ensaio, constante do volume $A$ parte do fogo (primeira ediçáo em 1949), Maurice Blanchot traça um percurso de análise da literatura bem próprio, partindo de um discurso filosófico hegemônico, centrado principalmente no pensamento hegelia$n^{2}$. Para Blanchot, o trabalho literário deve ser tomado tanto como processo isolado em si quanto considerada sua inserção no mundo. No mesmo artigo, delineou pela primeira vez conceitos que, mais tarde, investigaria mais detidamente. Tẫo fundante em sua obra e essencial para compreendê-la quanto de difícil leitura, o ensaio permite questionar a relação entre escritor, obra, 
linguagem, palavras e coisas; nele igualmente estâo presentes a morte na literatura, uma releitura do surrealismo, a questão da morte do autor (em que ele preconiza a reglorificaçáo da obra), seu resgate de Hegel e seu embate com Sartre - constituindo, nesse caso, o enfrentamento da noção de escritor engagé pela proposição do fora, mote deste artigo.

"A literatura e o direito à morte" mostra-se como resposta a Sartre que, em Que é a literatura?, afirma a literatura de prosa como agente de viés moral, engajada na História e na necessidade de transformação do mundo ("Parler c'est agir"); agente formador, por sua ação, da própria ideia de liberdade. Blanchot refuga o existencialista, ao negar tais implicaçóes e dessubordinar a literatura daquela "propaganda moral". A obra não busca um fim no mundo - sua causa é a própria questão que a gerou. Karl Erik Schøllhammer assinala que esse modus operandi "não reside numa nova objetividade do fato contingente, mas na maneira como o real é rendido pela escrita" ${ }^{3}$. É a essa ausência de objetividade moralizante, a esse continuum discursivo que determina a impossibilidade de seu fim que Blanchot atribui todo o poder transformador da escrita. É nessa morte do mundo, que também é sua total presença, que está sua potência.

Vasconcelos afirma que a crítica blanchotiana aproxima-se da escrita "de modo a melhor atentar para o funcionamento das redes culturais, temporais, em que a literatura se dispóe e a partir das quais afirma seu lugar de ford" ", lugar pleno de possibilidades que se habilita graças à "tensão de seu próprio desaparecimento na fronteira dos saberes" , chamando para si o signo da morte, existente no traçado desse desaparecimento. Entenda-se a morte aqui, no entanto, como liberta da individualidade, pois "apesar de manifestado numa individuaçáo, o trabalho mortal é experiência comum, extensiva a qualquer-um"'.

Blanchot principia afirmando que a literatura se inicia no momento mesmo em que ela se torna uma questão - sua própria questão. As questôes que emergem desse processo podem ser respondidas pelo (e no) fazer literário, uma vez que é na literatura e no seu fazer que "repousa silenciosamente a mesma indagação, endereçada à linguagem, por trás do homem que escreve e lê, pela linguagem que se tornou literatura"'. A linguagem e o homem que a produz: esta díade essencial à literatura abriga o imenso potencial volitivo de uma pergunta misteriosa porque parceira de uma resposta inarticulável, inominável. A ex-
3. SCHØLLHAMMER,

Karl Erik. Fiçãa brasileira

contemporânea, 2009, p. 107.

4. VASCONCELOS, Mauricio Salles de. "Blanchot, paradoxo plural", 2002, p. 144.

5. Ibidem, p. 144

6. Ibidem, p. 153.

7. BLANCHOT, Maurice. $A$ parte do fogo, 1997, p. 291. 
8. Ibidem, p. 297 periência da literatura substantiva uma condensação poderosa: dissolve aquele "que lê" daquele "que escreve", favorecendo a emergência da experiência da literatura. Ato de apropriação do que não lhe é próprio, pelo leitor, acaba por desabilitar aquele aparente binômio excludente da leitura e da escrita. Iluminados pela linguagem, os dois personagens dissolvem-se (decretam sua morte?) na experiência da literatura. Assim, se a morte do autor é aqui anunciada, no mesmo movimento é preterida a noção do escritor apartado do mundo, morador de um único plano reservado às almas "iluminadas", capazes de produzir literatura. Em vez disso, aquele que produziu a obra literária desaparece para dar lugar à linguagem, lugar de trânsito (sem gestos majestáticos de qualquer lado) de quem lê e quem escreve.

Para Blanchot, portanto, a obra é construída também - e sobretudo - fora do escritor. É vão pensar que as operaçóes literárias não sejam absorvidas pelo céu de contingências do mundo público, pelo contato daquela obra com outros olhares que não o seu. O pensador francês resgata o que Hegel chamaria de $a$ própria Coisa, operação identificada com o leitor, ponte entre a impossibilidade da obra e o movimento da obra em direção ao mundo:

Todavia, sua experiência não é nula: escrevendo, ele próprio se experimentou como um nada no trabalho e, depois de ter escrito, faz a experiência de sua obra como algo que desaparece. A obra desaparece, mas o fato de desaparecer se mantém, aparece como essencial, como o movimento que permite à obra realizar-se entrando no curso da história, realizar-se desaparecendo. ${ }^{8}$

O esforço de presença do mundo na obra é o que a mantém, mesmo sabendo-se de antemão que esse esforço é impossibilidade em si mesmo: "a meta não é o que o escritor faz, mas a verdade do que faz". Nesse sentido, a obra resume aquele movimento de dispersão de sua origem em direção à sua verdadeira existência. O nulo e o nada sobrevêm como a verdade de toda obra. Desassistida por um autor que deixou de sê-lo, resta a ela sobreviver dos cacos de memória de que foi gerada e entregar-se ao fundo de tudo isso, à sua real meta: a experiência da apropriação daquela realidade de nada pelo leitor. Sua verdade: nascida de um caldo primordial de experiências inalcançáveis em sua perfeição, a ela resta o castigo de sua experimentação em outrem. Em outro texto ("A leitura de Kafka") do mesmo livro $A$ 
parte do fogo, Blanchot comenta que Kafka, ao pedir ao amigo Max Brod que queimasse seus originais, buscava o fundo desse anonimato, essa ausência absoluta; mas, ironia ou náo, o fato de seu amigo não ter atendido a seu pedido tornou o autor de $A$ metamorfose a um só tempo glorioso e desgraçado:

[...] quando vemos esta obra, principalmente silenciosa, invadida pela tagarelice dos comentários, esses livros impublicáveis sendo objeto de infindáveis publicaçôes, essa criação atemporal convertida numa glosa da história, perguntamonos se o próprio Kafka náo teria previsto um táo grande desastre em tão grande triunfo. ${ }^{?}$

Essa indiscrição entregou-o ao público, e o enigma, que antes se mostrava indecifrável, trama-se como reprodutível e contingencial porque tornado real, produto, livro. Nessa operação de tornar a intenção de apenas escrever o mundo no próprio mundo, de mergulhar aquela obra essencial no que é contingencial, uma parte daquilo que era todo o seu mundo está irremediavelmente perdida, pois a dispersão inerente a toda experiência literária despotencializa aquelas verdades de origem.
9. BLANCHOT, Maurice. $A$ parte do fogo, 1997, p. 9.

10. VASCONCELOS, Mauricio Salles de. "Blanchot, paradoxo plural”, 2002, p. 149.

11. Ibidem, p. 150.

12. BLANCHOT, Maurice. $A$ parte do fogo, 1997, p. 300.

Também a ausência do escritor não é totalmente afirmativa, pois igualmente mostra-se pura presença; ele encontra-se, movimento contínuo, diluído e presente em todo o processo da escrita. Essa ausência não afirma a troca mecânica de ausência/ presença ou um processo de início e fim atrelado a um "sujeito esclarecedor do vínculo problemático" ${ }^{10}$ com o mundo, como proposto pelos frankfurtianos. Antes disso, mostra-se como processo permanente de compreensão e questionamento, excluídas aqui a tentativa de acerto histórico pelo personagem problemático ou aquela "síntese superior do ser, seja em nome da autenticidade (Heidegger) seja em nome da História (Hegel, Sartre)"11. No entanto, jamais deixamos de entrever a figura do escritor como ponto de ligação do trinômio autor-obra-leitor:

O escritor sem nome, pura ausência dele mesmo, pura ociosidade, em seguida o escritor que é trabalho, movimento de uma realização indiferente ao que realiza, a seguir o escritor que é resultado desse trabalho e vale por esse resultado, e não pelo trabalho, real tanto quanto é real a coisa feita, depois o escritor, não mais afirmado, mas negado por esse resultado e salvando a obra efêmera salvando dela o ideal, a verdade da obra. ${ }^{12}$ 
13. Ibidem, p. 302.

14. Ibidem, p. 303-304.
O escritor não exclui aqueles elementos, mas os relaciona; é nessa fatalidade, nesse movimento incessante de afirmação e anulação, de conciliação improvável, que sua existência, e a existência daquilo que para ele é verdade, se afirmam. Esse descompromisso autoral com o resultado da obra é a moral de quem escreve:

[...] ele deve se opor a si mesmo, negar-se afirmando-se, encontrar na facilidade do dia a profundidade da noite, nas trevas que nunca começam a luz certa que não pode terminar. Deve salvar o mundo e ser o abismo. ${ }^{13}$

Essa operação nem aparta a literatura do mundo nem lhe impôe a necessidade concreta de traduzi-lo e transgredi-lo. Não é dever da literatura transformá-lo, mas acaba por fazê-lo à sua maneira. Apesar de ele gestá-la a partir de um nada ausente do mundo, o escritor precisa destruir a linguagem realizável, erigi-la diferente do que era e assumir a negação daquilo que afirma. Assim, a obra está no mundo graças à sua ausência dele, pois é na diferença entre o projeto da obra e a própria obra que está o fazer literário; e é nesse lugar de desconstrução que a linguagem afirma-se como elemento constituidor de uma nova realidade:

O livro, coisa escrita, entra no mundo, onde cumpre sua obra de transformação e negação. Também é o futuro de muitas outras coisas, e não apenas livros, mas, pelos projetos que podem dele nascer, pelos empreendimentos que favorece, o conjunto do mundo do qual é o reflexo mudado, fonte infinita de novas realidades, a partir de que a existência será $\mathrm{o}$ que não era. ${ }^{14}$

Blanchot nega a obrigação de a literatura existir para agir no mundo, embora seu processo acabe por fazer com que aja. Seu engajamento está nessa displicência enganosa. Seu trabalho está nessa ausência (que é presença em um sentido não correspondente, contrarrespectivo) do mundo, pois é a partir desse duplo de repetição e descolamento, de representação de uma realidade dada e de refundaçấo de um mundo com suas regras próprias, que a obra se cumpre.

Assim, a chamada literatura engajada é reconcebida por Blanchot, que condena a cisão entre o engajamento social determinista e o envolvimento pessoal com os movimentos da sociedade. Em vez disso, verifica-se um empenho comunitário desa- 
trelado de um princípio centrado no coletivismo como síntese resultante de um movimento dialético.

Aqui fica caracterizada a escrita como processo que leva a um saber extremo - e, portanto, a um estar presente no mundo. As demandas que supre achegam-se ao âmbito subjetivo, esmaecendo-se quando frente a frente com a visada sócio-histórica, por buscarem soluçóes "segundo os caminhos do tempo num ideal acima do tempo, vazio e inacessível"15. A obra, segundo Blanchot, "prioriza aquele que viveu sobre aquele que escreveu"16, o que altera a relação de forças entre a experiência e a escrita. No ato da escrita, o escritor torna-se senhor de tudo, pois age sem limites sobre aquele mundo e aquela linguagem, tornando-se dono de um "poder próprio, poder de faltar com a verdade" ${ }^{17}$. Assim, a literatura nâo busca um acerto de contas com a história ou um fim social para a ação por ela supostamente estimulada, apenas procura sugerir suas perguntas como suportes para o questionamento de uma realidade, a partir de um lugar marginal àquele espaço social. Esse lugar não se coloca fora do mundo; está no mundo, mas não se deixa cegar por suas contingências cotidianas - e é por esta característica que se afirma criticamente perante ele: sua força está nesse aparente desinteresse.

Nesse espaço, permite-se afirmar outra verdade, não a verdade limitadora contingencial, mas a verdade indecifrável daquele mundo extremo, lugar da hesitação que desabilita o suporte dialético, pois "não há todo a ser reafirmado [...] no espaço produzido pelos livros dos criadores de literatura" ${ }^{18}$. Sua ação é menos contingencial que reflexiva. Ele "coloca à nossa disposição toda a realidade", e esse tudo possível não é exequível fora da obra. Nesse sentido, a objetividade absoluta é implausível, pois o mundo concreto demanda recortes e limitaçóes para o seu entendimento, irmanando-o com a finitude. Já a obra literária e o espaço nela exercido via linguagem dispóem a quem a lê todas as potencialidades de compreensão: aquele mundo é um tudo. Blanchot esclarece tal relação entre mundo real e criado, concreto e literário (parte da citação já referenciada anteriormente):

O imaginário não é uma estranha região situada além do mundo; é o próprio mundo, mas o mundo como conjunto, como o todo. Por isso não está no mundo, pois é o mundo, tomado e realizado em seu conjunto pela negação global de todas as realidades particulares que nele se encontram, por sua colocação fora do jogo, sua ausência, pela realização dessa mesma ausência, com a qual começa a criação literária, que se dá a ilusão, quando se volta para cada coisa e cada ser, de criá-los, porque agora os vê e os nomeia a partir do todo, a partir da ausência de tudo. ${ }^{19}$
15. BLANCHOT, Maurice. $A$ parte do fogo, 1997, p. 304.

16. Ibidem, p. 9.

17. VASCONCELOS, Mauricio Salles de. "Blanchot, paradoxo plural”, 2002, p. 148.

18. BLANCHOT, Maurice. $A$ parte do fogo, 1997, p. 304.

19. Ibidem, p. 305. 
20. Ibidem, p. 316.
Essa dimensão do mundo, expressa por um posicionamento fora dele próprio, torna transformadora a ação do escritor: aquele tudo que ele cria desencarcera-se das contingências, permitindo-lhe tratar a realidade sem amarras. Aqui nada se opera, mantendo-se a dicotomia dentro-ou-fora-do-mundo. Ao contrário: tal como a obra, o escritor é ser de papel, cujas ações só se validam quando afastadas das contingências, mas, no entanto, ele está no mundo - graças à sua ausência dele. Esse poder não advém do mundo, mas da sua ação criadora que, por revolucionária, é sua liberdade.

O processo de apropriação do real por meio da linguagem literária revela-se momento de dispersão, pois algo que antes ali havia desaparece, o que era de origem jamais será plenamente restabelecido e os elementos daquela estranha equação nunca mais poderão ser restaurados ou reproduzidos: a morte por diluição daquilo que foi unicamente enunciado acompanha o processo. O empenho da literatura está em perseguir o momento que precede aquela apreensão, o momento da verdade original da coisa, o gato como gato, o Lázaro do túmulo, o princípio, o caos da própria coisa nomeada, irremissível. A esperança de reatar aquela antiga aliança (entre o que é nomeado e a própria coisa) é a obrigação da literatura, e sua única chance de êxito está na linguagem: "Não é a noite; é sua obsessão; não a noite, mas a consciência da noite que sem descanso vela para se surpreender e por causa disso, sem repouso, se dissipa. Não é o dia, é o lado do dia que este rejeitou para se tornar luz" ${ }^{20}$.

O jogo se constrói não mais como reflexo do mundo dado, mas como tentativa de relançamento da referencialidade da coisa original, e a palavra poética torna-se, para a coisa nomeada, "mais um refúgio que uma ameaça", é sua chance de manter-se, mesmo desaparecida, de alguma maneira, viva. A sua precisão, a exatidão viva da palavra comum, enquanto coisa, se apaga para dar lugar ao estranho poder de significar. Daí emergem os dois vieses para o entendimento do processo de nomeaçáo cometida pela palavra literária: o da negaçáo e o do reconhecimento da impossibilidade de reconstituição da aliança com o nomeado. A partir desses movimentos, a literatura se posta sempre além do mundo, à sua margem, extrapolando-o enquanto realidade dada e reinventando-o à sua maneira, sem deixar de marcar o mundo e suas "bordas": o além-mundo. Não consiste em sua negação, mas no seu vislumbre privilegiado, porque a partir de um lugar ao largo, marginal a ele. É desse lugar que ela emana seu poder 
de falar das coisas e de se ocupar dos homens e termina por admitir em si mesma sua autoridade mais potente, seu engajamento mais veemente. Desse lugar outliner, torna-se incômoda e até perigosa. Sua aparente distância da realidade faz com que atue sobre o mundo como a adaga que penetra um corpo estranho, sem compromissos que a aprisionem na manutençáo da vida daquele corpo, ao mesmo tempo aliada e descompromissada, "indeferida pela história":

[...] existe em sua natureza um deslizamento estranho entre ser e não ser, presença, ausência, realidade e irrealidade. O que é uma obra? Palavras reais e uma história imaginária, um mundo onde tudo o que acontece é tirado da realidade, e esse mundo é inacessível; personagens que se querem vivos, mas sabemos que sua vida é feita de não viver (de permanecer ficção). ${ }^{21}$

A materialidade da apropriação literária pode ser duvidosa, mas a materialidade do livro é real, e a realidade daquela ficção é muitas vezes muito mais concreta do que o próprio real, pois a realidade da linguagem a impregna de si mesma. Isso faz com que a literatura exista, seja a expressão inventiva de tudo o que não pode ser exprimido e adquira, por isso, uma força insuspeitada. Ela evoca a náusea ao mundo, permite que se sinta estranho a ele, catapulta quem a experiencia para aquele lugar "de borda"; trabalha no mundo porque dele descomprometida, situada fora do lacre imobilizante da palavra comum: exterioridade radical praticada graças à sua visada subjetiva. Atribui, como direito, um sinal negativo ou positivo, mas oposto, a tudo que toca; atribui não o signo materializador de uma historicidade e constituidor da razão ${ }^{22}$, mas desmistificador do poder do negativo, a própria morte (a historicidade em seu ponto limite, não ideal); joga com a hesitação na qual existe o assertivo monolítico; afirma a instabilidade como sua arma mais poderosa; abriga o excesso e o abuso que secretamente habitam as palavras porque não procura afirmar, mas buscar as indagaçóes intermitentes, de que trata Blanchot num ensaio sobre Nietzsche, no mesmo livro do ensaio que estudamos:

É como se, no âmago da literatura e da linguagem, para além dos movimentos aparentes que as transformam, estivesse reservado um ponto de instabilidade, um poder de metamorfose substancial, capaz de tudo mudar sem nada mudar. Essa instabilidade pode passar como o efeito de uma força desagregadora, pois por ela a obra mais forte e mais carregada de força pode se tornar uma obra de desgraça e ruína, mas essa desagregação é também construção, se subitamente por ela o desespero se faz esperança e a destruição se faz elemento de indestrutibilidade. ${ }^{23}$
21. Ibidem, p. 326.

22. VASCONCELOS, Mauricio Salles de. "Blanchot, paradoxo plural", 2002, p. 148.

23. BLANCHOT, Maurice. $A$ parte do fogo, 1997, p. 329. 
O efeito de tomar o sinal das coisas e transformá-lo em seu oposto denota o poder da literatura sobre o mundo, pois a morte existente nesse shift afirma a origem daquilo que é mencionado pela escrita sem, no entanto, resgatá-la por completo, sob pena de debilitar seu poder imensurável de questionamento.

Em $A$ conversa infinita, Maurice Blanchot afirma que o poder, o mundo da dominação e da história, das constâncias, estaria a serviço do dia, enquanto que a arte, a literatura e outras formas de dissipação transgressiva das açóes cotidianas estariam a serviço da noite. Aqui vemos a dimensão do Fora se relacionando com a noite, com o afastamento dispersivo, a alienaçáo que, por conta de sua autonomia, alça-se como elemento libertador. A literatura não serve a ninguém, e igualmente não serve para nada. É nessa inutilidade que está sua força transgressora. Por não existir no mundo, está nele presente com uma potência devastadora de criar questionamentos sobre aquilo que nunca foi abalado pela linguagem cotidiana. Ela serve, portanto, para elaborar experiências potencialmente transformadoras, intensas, transgredindo o real para que aquilo tratado por ela adquira, por si, toda a potência de transformação que puder alcançar.

Também não se poderia analisar a literatura pela ótica funcional da utilidade (ótica utilitária, linguagem cotidiana), visto que ela tem como fim ela mesma. Aqui o que conta é a experiência apartada do poder, é a contrainformação residente em todo ato literário, estando a literatura associada a uma resistência ao poderio das palavras de ordem, palavras de poder, cristalizaçôes da linguagem, destruição da ideia de tradição, sabotagem, encontro com o vazio, desouvrement.

Essa sabotagem da língua vem favorecer não só um questionamento puramente linguístico ou estético, abrangendo igualmente a dimensão política. Desestabilizar um modo de pensar é transgredi-lo; é, por via da prática de uma linguagem não majoritária e avessa a cristalizaçôes cotidianas, exercitar uma ótica política menor, tornando aquela obra engajada. A minoração da linguagem caracteriza o potencial transgressivo da literatura, intrínseco à experiência do escrever literário.

É nessa transgressão que o fora se evidencia como ponto de partida para a compreensão de comunidade, constrastiva com o conceito de sociedade. Se esta se constrói a partir de certas 
demandas homogeneizantes e da ideia de um vínculo comum de compartilhamento de uma identidade, a comunidade os nega. Assim, a partir de Jean-Luc Nancy (2000), a ideia de um comum desapareceu, e sua perda tramou-se como intrínseca ao conceito de comunidade. A ideia de sociedade, então, faria prescindível a comunidade; a perda daquele comum tramaria a constituição da questão comunitária. Opostas, sociedade e comunidade: se uma caminha para a totalização, a segunda a desautoriza. Blanchot, partindo de recepção peculiar de George Bataille, retoma a questão comunitária em "A comunidade inconfessável" (2013).

Se a sociedade se constitui na relaçáo do mesmo com o mesmo - uma vez que se supóe o homogêneo como característico de seus expedientes - a comunidade se compóe a partir do salto do mesmo para o outro. Náo se trata de um movimento de partes que se direcionam para a composição de um todo, de um apaziguamento das franjas da subjetividade em nome de uma falsamente monolítica integridade, mas da afirmação de que a comunidade se constitui a partir daquilo que Bataille considera como "princípio de incompletude" ("principe d'incomplétude"): uma falta que não busca a alteridade para se completar, mas gera um movimento de choque, oposição, desafio, desconstituição e instabilidade a partir do qual afirma a incerteza de sua integridade.

O ser não busca ser reconhecido, mas contestado: ele vai, para existir, em direção ao outro que o contesta e por vezes o nega, a fim de que ele não comece a ser senáo nessa privação que o torna consciente (está aí a razão de sua consciência) da impossibilidade de ser ele mesmo, de insistir como ipse, ou caso se queira, como indivíduo separado. ${ }^{24}$

Dessa forma, a comunidade, aquela que busca, no extremo, sua desconstituição por conta de seu viés desestabilizante, afirma-se acima de tudo finita, uma vez se constituir na própria finitude dos seres que a compóem. Por isso, revela-se fraude a afirmativa de que a comunidade é composta por vivos: sua constituição e longevidade se constróem pela memória dos seus mortos e de suas açôes, gloriosas ou não.

Tanto o fora se afasta daquela visada glorificante de transformação social quanto a comunidade se desirmana da tentativa unificante (e também glorificante) da constituição de um todo baseado num mesmo. Seu poder, tanto quanto o do fora, está na insuficiência de seu trânsito no mundo; não busca pôr um fim ao confronto, mas pelo encontro com certo exagero de uma falta "que se aprofunda à medida que ele vá se preenchendo" 25 .
24. BLANCHOT, Maurice. A comunidade inconfessável, 2013, p. 17.

25. Ibidem, p. 20. 
27. BLANCHOT, Maurice. $A$ parte do fogo, 1997, p. 298.
A obra literária náo se constrói apenas a partir do dentro do escritor ou dela, obra, mas de fora de ambos. A partir de transformaçóes da linguagem, da cultura, de livros lidos e comentados, assim como de elementos materiais, como tinta, papel, computador, e outros mais íntimos do próprio ser-que-escreve. O fragmento do poema de Herberto Helder assinala tal conjunçáo de universos.

Estou deitado no meu poema. Estou universalmente só, deitado de costas, com o nariz que aspira, a boca que emudece, o sexo negro no meu quieto pensamento. Batem, sobem, abrem, fecham, gritam à volta da minha carne que é a complicada carne do poema. ${ }^{26}$

O escritor deve destruir a linguagem, a cultura, suas referências, para reelaborá-las numa obra, que certamente será uma realidade. Antes de escrever a obra, o escritor náo tinha nada tendo tudo: a cultura, os livros já lidos por ele, as contingências do mundo, mas, todos dispersos, eram como os materiais usados por aquele que construiu o aquecedor. A obra, entáo, tornou-se uma realidade nela mesma, podendo ser fruída sem que se saiba como ou por que foi criada. No entanto, as contingências, as necessidades e os embates do mundo são, nela e nele, obra e escritor, referências presentes e necessárias, pois a literatura existe no mundo e a partir dele. A história, a experiência e as necessidades do mundo são o pano de fundo que leva o homem ao escritor, $\mathrm{e}$ o texto, a linguagem, à obra literária.

Nessa experiência, a real meta do escritor não é mais a obra efêmera. Mas, além da obra, a verdade dessa obra, em que parecem se unir o indivíduo que escreve, poder de negação criador, e a obra em movimento, com a qual se afirma esse poder de negação e superação. ${ }^{27}$

O exercício dessa negação utiliza como matéria de suporte a própria linguagem, elemento a partir do qual as construçôes do ficcional são tramadas. Decerto que aqui não se refere à linguagem comum, utilizada quando nomeamos um objeto real, na qual as referências às coisas do mundo são diretas e inequívocas e os signos se relacionam diretamente com seu significado. Refere-se à linguagem literária.

À primeira vista, o interesse da linguagem é, portanto, destruir com seu poder abstrato a realidade material das coisas, 
e destruir com o poder de evocação sensível das palavras esse valor abstrato. Tal ação deve nos levar muito longe. Quando a palavra se contenta em nomear um objeto, não nos livra dele. O fino envelope da palavra usual cede à pressão da coisa que ela designa; como é costumeira, ela se desvanece assim que é pronunciada e nos entrega à sua presença, da qual nos deveria defender. ${ }^{28}$

A linguagem da literatura não é a coisa, mas, infiel a qualquer tentativa de representação exata, é o equívoco, a assunção da finitude e da impossibilidade da significação direta e de se totalizar o real, assumida sua imperícia para representá-lo. A coisa só é coisa quando não é observada, pois qualquer observação denota algum olhar que escolhe: ângulos, sombras e características que jamais serão integralmente a coisa. A linguagem literária deixa de ser aquele instrumento para designar coisas do mundo e passa a construir uma nova realidade, não cotidiana, não familiar e desconhecida, propondo outra função para a palavra; função esta demolidora de afirmaçóes cotidianas e fundadora de outro mundo. Daí advém a necessidade de a linguagem ficcional destituir as coisas de sua realidade, de desorganizar a orientação perfeita do signo para a coisa e implodir a cadeia de significaçóes que ligam as coisas às palavras que as designam.

Graças a essa experiência exteriorizante que desapropria o objeto da linguagem como fixaçáo das coisas, a essa visada fora de qualquer enquadramento objetivo, a linguagem literária evoca um "assassinato diferido", uma transformação da palavra, de instrumento de significação, ação em comunidade e comunicação direta, em negação do mundo e das coisas. Ela não busca representar, mas criar uma realidade instituída a partir da negação e da impossibilidade de se relacionar. A ambiguidade daí resultante torna-se a justificativa de todo ato literário, que permite a aproximação de pares opostos como vida e morte, presença e ausência. Nesse sentido, a literatura emerge como elemento confrontador de domínios, uma vez que promove, a partir da realização de seus objetos, o desaparecimento ou destituição de seus complementares do real. Admirável concisão: Blanchot conclui dizendo ser a palavra a vida desta morte.

Se o frasear cotidiano reafirma nossa inserção no mundo, a experiência literária nos retira dele para nos reintroduzir no espaço da literatura, mundo fundado numa vivência que se nos apresenta como outra versão do mesmo mundo, percurso diversamente nomeado por Blanchot como errância, deserto, abismo: o fora. Nesse lugar tangencial, designado como espaço literário por Blanchot, há que se perguntar de quem é a voz. Se estamos no reino da pergunta, quem a faz? Quem fala, questiona Nietzsche. Mallarmé responde: a própria palavra. Tomando as palavras do poeta, pode-se replicar: o enunciador, no espaço da literatura, é a obra literária, sua linguagem que toma para si
28. Ibidem, p. 37. 
a gênese de um mundo inaugurado e, em última instância, a superfície do lago que divide tenuemente os dois domínios, real e ficcional, dividindo, sem excluir, o poder de fogo de ambos: a palavra literária. É a "parte do fogo" de Blanchot. Fogo que consome e reacende a existência da palavra-fênix, morta na sua existência cotidiana para revivificar-se, palavra-Lázaro, no universo fundado pelo ato literário.

A morte está naquela palavra e naquela linguagem fundantes do espaço ficcional; uma morte que, afastando-se do seu significante, designa seu contrário, pois não se caracteriza como extinção. Ao contrário, amalgama os estados de existência da palavra e da linguagem, lagarta e ser colorido que voa, o mesmo ser, destituído de si e criado a partir de si, de sua própria destituição, mantendo ao mesmo tempo o longe e o perto, o semelhante e o inconciliável, como verdades. Blanchot encerra as motivaçóes da literatura neste direito a uma morte plurissignificada. Nela vê-se vida e morte conciliando-se para a constituição de um ato literário, a partir de uma escrita erigida por uma linguagem que não pretende se impor como verdade objetiva do mundo, mas como possibilidade de se tornar elemento da literatura e, no limite, obra.

Maurice Blanchot, no capítulo inaugural de $O$ livro por vir (2005), toma o Canto XII da Odisséia de Homero como objeto de análise de questóes tais como a dispersão narrativa e o imaginário. Assim, tome-se um relato breve do Canto homérico: após conhecer o Hades, o mundo dos mortos, Ulisses resolve desafiar o canto das sereias, cuja canção se tornava irresistível se escutada por ouvidos mortais. Para isso, ordena que seus companheiros protejam seus ouvidos com cera, para que fiquem alheios àquele (en)canto. Igualmente determina que o amarrem ao mastro da embarcação sem a proteção da cera. Com isso, ao mesmo tempo escuta o canto das sereias e se vê impossibilitado de ceder a ele. Este trecho da Odisséia pode servir primeiramente para ilustrar os desvios da razão ocidental, incapaz por si só de compreender o mundo.

Caros amigos, não basta que um só, ou que dois, fiquem cientes do que respeita ao destino que Circe preclara me disse. Não; quero tudo contar-vos, porque procuremos a morte conscientemente, ou possamos fugir do Destino funesto. Manda, em primeiro lugar, que as divinas Sereias, dotadas de voz maviosa, evitemos e o prado florido em que 
se acham. Somente a mim concedeu que as ouvisse; mas peço a vós todos que me amarreis com bem fortes calabres, porque permaneça junto do mastro, de pé, com possantes amarras seguro. Se, por acaso, pedir ou ordenar que as amarras me soltem, mais fortes cordas, em tomo do corpo, deveis apertar-me. ${ }^{29}$

Fica claro que Ulisses deseja o contato com aquela canção. Amarrado e impossibilitado de ceder àquela tentação interrena e distante do risco de se deixar levar pelo abismo que ela representava, busca compreender o que de desconhecido havia nele. Segundo Blanchot, sempre houve, entre os homens, um "esforço pouco nobre para desacreditar as sereias" 30 (Cabe questionar se tal atitude não seria herança da ideia platônica da insuficiência da poesia para promover a compreensão do mundo ${ }^{31}$ ). $\mathrm{O}$ "canto inumano" das sereias criava nos homens o desejo secreto, o "prazer extremo de cair", o devir do abismo, a aproximaçáo com o insólito, com o deslumbramento. Tal convite às profundezas primordiais do homem era combatido com o suposto bom senso da racionalidade, com as armas do saber ocidental binarizado (porque dividido entre o bem e o mal, o claro e o escuro - pura e dura objetividade), avesso a encantamentos e enigmas.

Amarrado ao mastro da embarcação, Ulisses é visto como a representação da obstinação radical do homem do Ocidente em se manter afastado da dúvida. Cedeu e gozou do abismo sem enfrentá-lo; imaginou não correr riscos e não ter que se confrontar com as consequências de seu gozo seguro. No entanto, o imponderável prevaleceu, e Ulisses não saiu sem arranhōes de seu voyeurismo de epopeia. O canto das sereias passa a dar o tom ficcional e poético ao Ulisses épico, deus da técnica, pois driblou as artimanhas do odisseu e foi responsável por retirar-lhe da razão a preponderância absoluta. Ao contrário dos marinheiros que antes haviam se aproximado daquele canto, pois espreitar o desconhecido que aquela canção representava era tornar-se desconhecido para o que se conhece de si mesmo, Ulisses sobrevive e retorna, diferente daquele que entrou no universo das sereias.

Ulisses não saiu porém ileso. Elas o atraíram para onde ele não queria cair e, escondidas no seio da Odisséia, que foi seu túmulo, elas o empenharam, ele e muitos outros, naquela navegação feliz, infeliz, que é a da narrativa, o canto não mais imediato mas contado, assim tornado aparentemente inofensivo, ode transformada em episódio. ${ }^{32}$

Ele tenta ludibriar-se com as amarras enganosas da racionalidade, com o rechaço à entrega extrema, mas os contrários se entrelaçam, e uma porção do saber não terreno das sereias insinuou-se nos ouvidos de Ulisses. Com isso, a irresistível cópula dos dois domínios, do terreno e do interreno, da técnica
29. HOMERO. Odisséia, 2002, p. 166.

30. BLANCHOT, Maurice.

O livro por vir, 2005, p. 5.

31. Entenda-se: poesia tida como engano, simulacro, estabelecimento de uma cópia do mundo das ideias - este sim autenticado, pois origem de tudo o que existia sobre a Terra.

32. BLANCHOT, Maurice. O livro por vir, 2005, p. 6 
33. Aqui falamos das obras Alice no país das maravilhas e Alice do outro lado do espelho, de Lewis Carroll.

\section{BLANCHOT, Maurice. \\ O livro por vir, 2005, p. 10.}

35. Referido por Benjamim a partir do quadro "Angelus Novus", de Paul Klee.

36. BENJAMIM, Walter. Magia e técnica, arte e política: ensaios sobre literatura e história da cultura, 1994, p. 166. e daquilo que se chamou inspiraçáo, do inexplicável e do conhecido, mito e história, de um e de outro lado do espelho de Alice ${ }^{33}$ criou um Ulisses latitudinário e indefinível. Vislumbrador de interstícios, Ulisses ressurge como um exemplo adâmico pós-maçã, mais sabedor de mistérios, do real e do não real, do ficcional e do não ficcional.

Há, em Ulisses, aquela teimosia pensada que conduz ao império universal: sua esperteza consiste em parecer limitar seu poder, em buscar fria e calculadamente o que ele ainda pode, em face da outra potência. Ele será tudo se mantiver um limite, e o intervalo entre o real e o imaginário que, precisamente, o Canto das Sereias o convida a percorrer. ${ }^{34}$

É nesse ponto que Ulisses passa a residir um espaço limitrofe de dois domínios: o da razão e o das sereias; um representando o que o homem acha de si mesmo (senhor da razão, monumento da impassibilidade técnica); outro trazendo uma maneira diversa de se compreender e de se mover no mundo. Esse espaço rico de intervalos não nega, no entanto, sua dubiedade, antes fazendo-a prevalecer. Nega, sim, um ponto de chegada, uma pretensão a uma totalidade. Tal situação de interpolação de domínios não se resolverá, pois não há resposta para a dúvida ali instalada, assim como não há possibilidade de restauração daquela palavra adâmica benjaminiana, instauradora de eventos.

Cumpre aqui tomar o "anjo da história" de Benjamim ${ }^{35}$ como imagem exemplar dessa via de mão dupla entre dois domínios. Seus olhos sobressaltados miram um passado mítico, embebido na pura origem de escombros e eventos irreprodutíveis, mas seu corpo verga-se, conduzindo-se em direção ao futuro da reprodutibilidade narrativa ${ }^{36} \mathrm{e}$ das tentativas vấs de resgate daquele mito que se perdeu e se divorciou (talvez para sempre) da história dos homens. Assim, em vista desse caráter de impossibilidade de se chegar a um ponto final, a uma resoluçáo instauradora de uma aliança perdida entre a palavra e o mundo, deve-se considerar o universo literário como o lugar da instabilidade. Por sua vez, esse universo irmana-se com aquela metamorfose ulissiana, pois é no intervalo existente entre o Ulisses racional e seguro e seu outro, aquele "contagiado" pelo deslumbramento das sereias, que a palavra literária constrói seu espaço e nele reina.

Os dois domínios passam a residir o mesmo Ulisses, ele mesmo representando-se antes e depois de sua ressurreição, simulacro do anjo benjaminiano uterado na Odisséia, crisálida incompleta de si mesmo, contemplando a convivência de suas recém-instauradas duas porçóes. Essa mescla entre o claro e o obscuro, o conhecido e o ignorado, deslinda o próprio processo da escrita. Igualmente assinala que a literatura significa, antes de tudo, segundo Blanchot (1997), um direito à morte; assassinato 
do referente, do real incapaz do resgate do evento primordial, do real como o concebemos, estático e estanque, apartado do inefável, do inconcebível, do imaginado, sem o qual nem o próprio domínio do real mais consegue subsistir.

É como se, no âmago da literatura e da linguagem [...], estivesse reservado um ponto de instabilidade, um poder de metamorfose substancial, capaz de tudo mudar sem nada mudar. Essa instabilidade pode passar como o efeito de uma força desagregadora [...], mas essa desagregação é também construção. ${ }^{37}$

Não se refere aqui àquela morte definitiva que se conhece, final cut, interrupção extrema de um processo de vida, mas daquela outra morte, entendida como destituição ou desaparecimento, mais impalpável e implausível porque metafórica, trazendo para junto de si a ideia de um esmaecimento da monovalência do real sobre o fictício.

Se chamamos essa força de negação, ou irrealidade, ou morte, a morte, a negaçáo, a irrealidade, trabalhando no fundo da linguagem, ali significam a chegada da verdade ao mundo, o ser inteligível que se constrói, o sentido que se forma. ${ }^{38}$
37. BLANCHOT, Maurice.

O livro por vir, 2005, p. 329.

38. Ibidem, p. 330.

39. OLIVEIRA, Luís Inácio.

Do canto e do silêncio das sereias: um ensaio à luz da teoria da narração de Walter Benjamin, 2008, p. 125.

40. BLANCHOT, Maurice.

O livro por vir, 2005, p. 9.

Mais que uma porção da narrativa inserida na grande Odisséia, o Canto XII mostra uma "metáfora para descrever a própria palavra poética do narrador" ${ }^{39}$. Essa empresa igualmente perfaz um jogo de tessitura da memória, (de busca) das origens da narrativa e de construção dos seus elementos constitutivos.

É ouvindo o Canto das Sereias que Ulisses se torna Homero, mas é somente na narrativa de Homero que se realiza o encontro real em que Ulisses se torna aquele que entra em relaçáo com a força dos elementos e a voz do abismo. ${ }^{40}$

É sobre essa transformação de Ulisses (aqui espelhando os percursos de Alexandre e Darl) e suas significaçóes para a instituição da voz narrada, diversa daquela voz original e inaugural de eventos, daquele canto primordial representado pelas sereias, que será orientada a análise do Canto XII. Restauração e dispersão: o relato do encontro do herói da Odisséia com as sereias assinala a profunda transformaçáo nele subjacente, de canto de origem, transfiguração da palavra poética original, a canto narrado e apropriado pelo tempo e pela reprodutibilidade. 
41. Ibidem, p. 9.
Naquela regiáo mítica da narrativa primordial, do canto insólito das sereias, designado por Blanchot como "um desespero muito próximo do deslumbramento" ou "canto do abismo", palavra e mundo se mantinham inseparáveis. Nela, o canto das sereias, fundador enigmático, encerra a vocação da palavra poética como constitutiva da própria linguagem. Assim, é a partir daquele episódio da Odisséia que ocorre a metamorfose de Ulisses em narrador, evidenciada em sua experiência num duplo existir em dois mundos: o mundo das origens, mítico e fundador, e outro, racional, reprodutível e narrado.

Esse segundo mundo mostra-se incompleto por conta da dispersão subjacente em sua tentativa de reproduzir o irreprodutível, o mítico. A palavra do narrador só resiste se o canto primitivo, a palavra poética adâmica referida por Benjamim, desaparece e dá lugar ao canto eternizado da narrativa, considerada a forma de reprodução (ou sua tentativa frustrada) daquele momento primordial, de cena de origem. Assim, instituindo sua própria temporalidade, diferente da medida cronológica, a narrativa busca promover um espelhamento controverso do movimento infinito de restauração do evento primordial frente à finitude da experiência humana, constituindo nesse movimento um rompimento necessário para a constituição da literatura.

Mas essa tentativa de restauração de origens promovida pela intenção literária também se mostra como dispersão, uma vez que o resgate impossibilita-se, dado o caráter de instabilidade da palavra poético-narrativa. Essa instabilidade nada alcança e lança ao mar a promessa utópica de plenitude, de conquista daquele momento pleno de origem, e confronta-se com a incapacidade de realizar a pretendida conciliação final. Dessa forma, Blanchot afirma que, para a emergência da esfera do que se designou literatura, fez-se necessário o desaparecimento - e aqui surgem outros termos: esquecimento, perda, alheamento, desaliança - daquela palavra mítica fundadora, origem de todo evento e de toda narrativa. A dispersão mostra-se como resultante inescapável desse processo.

Sabe-se que as semelhanças e diferenças entre o que se denomina real e ficcional fazem mesmo parte da constituiçáo de ambos. Como domínios, eles não se destituem quando postos juntos, mas se complementam - entendendo seu caráter não teleológico como fulcral para a sua compreensão. Assim, pano de fundo para o debate, o imaginário emerge como ponto de apoio fundamental para a compreensão do que chamamos real.

O mundo, no limite, pode ser entendido como o pleno exercício do imaginário e "o imaginário não é uma estranha região situada além do mundo; é o próprio mundo"41.

Isso confirma que a lógica do espaço literário obedece a regras e limites próprios, ao mesmo tempo espelhando-se e dife- 
renciando-se de seu correlato real. Essa operação permite que um espelho que se permite permeável, um gato que ri ou um coelho obsessivo por relógios sejam aceitos como pertencentes ao jogo, à cumplicidade entre aquele que escreve/fabula $\mathrm{e}$ aquele que lê/escuta. A escrita/fabulação assoma como a ponte necessária para a construção do ficcional e para a própria afirmação do real, uma vez que fundamenta a constituição daquele e auxilia a compreensão deste. Maurice Blanchot toma por princípio, para essa co-construção, o espaço construído pelo fazer literário; espaço que se mantém fora de qualquer ordem objetiva e inaugura uma nova lógica de espacialização e temporalização, próprios do espaço literário. Assim, a crítica do filósofo francês afirma seu "lugar de fora", que se instaura graças à tensão gerada pelo enfraquecimento da perspectiva monovalente do real sobre o ficcional.

Outros exemplos não referidos de narrativas que abordam travessias são dignos de nota: Gregor Samsa e seu outro, monstruoso; a amada multinomeada do protagonista do conto Desenredo, de João Guimarães Rosa, que, de devassa, depois de fabulada por seu eterno apaixonado, torna-se a santa aos olhos de todos. Suas travessias os tornaram cientes de sua incompletude, senhores de suas dúvidas que nunca cessam. Cada um mereceria uma análise à parte.

Em todos eles, a fabulação permitiu o encontro dos domínios. Em todos eles, pode-se supor uma partida de xadrez significativamente ontológica entre um homem e a Morte; entre a narrativa que pende para a reprodutibilidade técnica e aqueles eventos primordiais míticos que, mesmo demandando, nunca alcançarão apropriação e repetição. Em todos eles, a narrativa, fundamentando ou transgredindo o real, franqueou o surgimento de uma terceira via a liquefazer fronteiras. Tal via permitirá o estabelecimento de um herói/protagonista convincente, prometendo gestos de pertença aos seus dois outros e desarticulando qualquer tentativa de uma totalização de si, uma vez que se entrega e se permite a eterna pergunta, encarnada no mergulho, no vislumbre do abissal existente em todo ato literário. 


\section{Referências}

BENJAMIN, Walter. Magia e técnica, arte e politica: ensaios sobre literatura e história da cultura. Tradução de Sergio Paulo Rouanet. 7. ed. São Paulo: Brasiliense, 1994. (Obras Escolhidas; Vol. I)

BLANCHOT, Maurice. A comunidade inconfessável. Tradução de Eclair Antônio Almeida Filho. Brasília: Editora Universidade de Brasília; São Paulo: Lumme Editor, 2013. A parte do fogo. Tradução de Ana Maria Scherer. Rio de Janeiro: Rocco, 1997.

O livro por vir. Tradução de Leyla Perrone-Moisés. São Paulo: Martins Fontes, 2005.

HELDER, Herberto. Ou o poema contínuo. São Paulo: A girafa, 2006.

HILL, Leslie. Blanchot: extreme contemporary. Londres: Routledge, 1997.

HOMERO. Odisséia. Tradução de Antônio Pinto de Carvalho. São Paulo: Nova Cultural, 2002.

NANCY, Jean-Luc. La comunidad Inoperante. Tradução de Juan Manuel Garrido Wainer. Santiago del Chile: Escuela de Filosofía Universidad ARCIS, 2000.

OLIVEIRA, Luís Inácio. Do canto e do silêncio das sereias: um ensaio à luz da teoria da narração de Walter Benjamin. São Paulo: EDUC, 2008.

SCHØLLHAMMER, Karl Erik. Ficção brasileira contemporânea. Rio de Janeiro: Civilizaçâo Brasileira, 2009.

VASCONCELOS, Mauricio Salles de. "Blanchot, paradoxo plural". Caligrama: Revista de Estudos Românicos. v.7, p. 143$155,2002$. 